\title{
OS SABORES DA LITERATURA OU: COMO A GASTRONOMIA SE APOIA NOS MODOS DE DIZER ${ }^{1}$
}

\author{
Maria Alzira Seixo \\ (Universidade de Lisboa)
}

\section{RESUMO}

Apoiado na relação entre os conceitos de "saber" e "sabor", abordada desde o já clássico O Prazer do Texto, de Roland Barthes, este trabalho compreende dois movimentos reflexivos: no primeiro, trata-se do modo como a Literatura, e em especial a Portuguesa, representa a Gastronomia, voltando a atenção a autores como Camilo Castelo Branco, Eça de Queirós, Vitorino Nemésio, José Saramago e António Lobo Antunes; no segundo movimento, destaca-se o modo como a Gastronomia utiliza a palavra para se explicitar a si própria, em termos que implicam um saber que apela para a "literariedade", isto é, para a insistência no "sabor" literário. ${ }^{2}$

PALAVRAS-CHAVE: gosto, Literatura, Gastronomia.

\section{ABSTRACT}

Based on the relation between the concepts of savoir and saveur (savoir [to know] and saveur [savor, flavor] have the same root in Latin), addressed since the already classic The Pleasure of the Text, by Roland Barthes, this work comprises two reflexive movements: the first is about the way Literature, and specially Portuguese Literature, represents Gastronomy, concerning authors such as Camilo Castelo Branco, Eça de Queirós, Vitorino Nemésio, José Saramago, and António Lobo Antunes; in the second, what is emphasized is the way how Gastronomy uses the word to make itself explicit in terms that imply a knowledge that appeals to the "literariness", i.e., to the insistence on the literary "flavor/ saveur".

KEYWORDS: flavor, Literature, Gastronomy. 
É conhecida a ênfase que Roland Barthes coloca na relação dos conceitos saber e sabor, no seu livro O Prazer do Texto, a partir do original francês savoir e saveur, e válida para a maioria das línguas românicas. Esse livro teve forte repercussão nos anos setenta, e a paronímia que releva nessas formas lexicais promove, segundo a tese do autor, uma alternativa de atracção mútua entre os dois conceitos, relacionados ambos com o gosto da Literatura. Esta mesma noção de gosto implica à partida uma oscilação, ou possível juntura, da dimensão estética de fenómenos culturais de carácter abstracto, apreendidos afectivamente, com uma outra dimensão, bem concreta e material, que é a de tipo gustativo. Assim, uma filosofia do gosto pode não se caracterizar apenas pelo raciocínio, em que predomina a argumentação justa que lhe confere o bom tom da adequação à matéria, mas se torna também atractiva no sentido da sua compreensão como que visual ("ver" é "compreender"), e por sugestões sensoriais múltiplas que se diriam recolhidas pelo paladar alargado, que agiria como se totalizasse a maioria das sensações de cada indivíduo em relação ao mundo e, por conseguinte, a cabal experiência de conhecimento de todos nós.

Gostar de alguma coisa ou de alguém é um sentimento afectivo que inclui muita dessa sensorialidade amplificada e mista que reúne praticamente todos os sentidos.

Ora quando falamos de Gastronomia, a dimensão saborosa da palavra revela-se fundamental. Porque, se o acto de comer gira primariamente em torno do instinto da fome e respectiva satisfação, que, na vida em sociedade, se completa com modos geoculturais próprios e distinções de civilização e estilos pessoais ou colectivos de vida (o que tem a ver com a designação mais genérca de Alimentação), a vertente gastronómica aqui considerada centra-se privilegiadamente em modos de confecção dos alimentos, que pressupõem uma elaboração dos materiais culinários utilizados, assim como em vários dos seus aspectos: a proveniência, o género de cuidados utilizados com os ingredientes, os modos de os misturar e apresentar, e as formas materiais, instrumentais, sociais e estéticas usadas para a ingestão. Todo um manancial de diversidades se nos propõe, portanto, num amplo leque de perspectivas, e, poderia mesmo dizer-se, numa arte de estar, dar e receber na mesa. Por isso, Gastronomia não é sinónimo integral do termo Culinária, se bem que sobre ela assente; e, se é certo que ambas servem a Alimentação, procurando corresponder ao que nesta é essencial - mas muitas vezes fugindo à sua ortodoxia mais comum, por esses seus laivos de certo modo "artísticos", que convocam a imaginação criadora e se manifestam por vezes no requinte da excepção -, a verdade é que a actividade gastronómica sempre se caracterizou por um forte alcance cultural, não raro ligado a raízes históricas, ambientais e patrimoniais. 
Como estudiosa de uma das artes maiores do património que é a Literatura, e tendo consagrado atenção a fenómenos da cultura de massas, que tantas vezes mescla as artes maiores com as menores (embora nenhum de nós possa determinar ao certo o que diferencia estes dois grupos) e até com manifestações sem arte nenhuma, ou pelo menos não reconhecidas como tal, seduzem-me na Gastronomia vários aspectos. Além da satisfação do meu próprio paladar, em várias acepções do termo, interessa-me sobretudo sublinhar aqui a capacidade da Literatura em representar, de modo rico e multiforme, a Alimentação, a Culinária e a Gastronomia, enquanto aspectos da vida quotidiana normalizada ou excepcional, de regiões ou cosmopolita, indo da prática humana mais rasteira (no dia-a-dia de quem nem pensa sobre o que come) ao nível mais elaborado da confecção do texto como alimento supremo, do corpo ou até do espírito. Por outro lado, num reverso que não é avesso mas reciprocidade, em características historicamente ligadas ao Modernismo, gostarei de destacar o modo como a Gastronomia utiliza a palavra para se explicitar a si própria, em termos que implicam um saber que apela para a "literariedade", isto é, para a insistência no "sabor" literário.

Digamos, pois, que, se o "saber", na teoria barthesiana, tem como um dos seus resultados a produção de um certo "sabor" (já que ler ou ouvir um texto bem escrito "sabe"-nos sempre bem!), poderá também verificar-se que há modos de "dizer o sabor" que podem aproximar-se do carácter literário (ou, pelo menos, alcançar como que uma transfiguração das designações correntes para a confecção dos alimentos), os quais acabam por ser poderoso estímulo, quando não forte componente, do próprio paladar que, comendo, se alcança.

É com esse propósito que me vou abeirar de algumas das melhores páginas da nossa literatura. E com idêntico intento aludirei em seguida às designações verbais que muitas vezes completam as iguarias que nos são oferecidas pela Gastronomia. O modo como Camilo ou Eça, Saramago ou Lobo Antunes, se referem à comida no universo dos seus romances não é menos despiciendo, porém, que a designação ancestral, e popularmente aceite, de pratos como "tripas à moda do Porto", "bacalhau com todos" ou "bife à café", que ultrapassam a mera descrição das correspondentes domésticas, e não rigorosamente similares, "dobrada com feijão branco", mais usada no Sul, o "bacalhau com batatas" da região Centro, ou o correntíssimo "bife com molho e batatas fritas". ${ }^{3}$ Assim como não é despicienda a forma como as ementas banais dos pequeníssimos resturantes mencionam o seu elenco de comidas, tanto quanto a que os "chefes" culinários de nomeada utilizam nos lugares caros e em voga, rejeitando a linguagem corrente e adoptando um estilo rebuscado, émulo do literário, que chega a ser "kitsch", mas por vezes atinge um sentido tangencial ao poético. 


\section{A LITERATURA E A REPRESENTAÇÃO DO MUNDO GASTRO- NÓMICO}

A representação da Gastronomia na Literatura é muito frequente. Remonta à Antiguidade, onde encontramos um poema do grego Arquestrato sobre a arte culinária, do séc. IV A.C., e, já no início da nossa era, surge em Roma, no romance Satiricon, de Petrónio, onde se destaca o episódio conhecido como a Cena Trimalquionis ( $\mathrm{O}$ Jantar de Trimalquião»), que descreve um banquete. ${ }^{4}$ Mas são talvez os textos bíblicos, quer no Antigo quer no Novo Testamento, que abundam em episódios relacionados com a nutrição, possuindo uma incidência particularmente moral que se liga aos intentos sociais postulados pelo Cristianismo, mas que criam uma simbologia particular. É o caso do emblemático "peixe”, numa religião que tem pescadores no seu núcleo fundador, ou do privilégio concedido à "comunhão" e às refeições comunitárias. Nesses textos sagrados, muitos dos episódios centrais relacionam-se com a cerimónia de comer, adquirindo o alimento um intenso valor espiritual. É o caso da Multiplicação dos Pães, das Bodas de Canaã e, muito em especial, da Última Ceia. Tal acontece também com a literatura medieval do Ocidente, com exemplo nos Cavaleiros da Távola Redonda e algumas referências na poesia, embora os valores artísticos da época se reportem sobretudo à espitualidade, transferindo progressivamente a alimentação para a esfera do simbólico.

Só durante o Renascimento, porém, com a valorização do corpo e a afirmação plena dos aspectos terrenos da existência humana, é que a nutrição entra na criação poética com um vigor inusitado, de que são exemplos, na Literatura Francesa, o famoso Pantagruel do grande François Rabelais, na Literatura Espanhola alguns episódios do Quixote, que remetem para Sancho Pança, e, em Portugal, trechos da literatura erudita como, nos Lusíadas, o da descrição do "escorbuto", a terrível doença que afecta os marinheiros nas grandes navegações devido à falta de alimentos frescos, ou a "Ilha dos Amores", episódio em que os manjares lhes são servidos mesclando-se aos prazeres sexuais proporcionados pelas ninfas. Durante os séculos em que o Classicismo se apura, XVII e XVIII, os valores da emoção racionalizada e da intelectualidade artística predominam na cultura ocidental, não sendo consideradas dignas de entrar na arte as actividades mais primariamente ligadas à matéria corporal, sobretudo as que são marcadas pelo instinto. Se exceptuarmos certa arte do Barroco, assim como outras formas de sensibilidade contra-corrente, verificamos que a alimentação não figura, em regra, nas obras desses duzentos anos, "grosso modo", e em parte do séc. XIX, mais ligado à impulsividade sentimental e à problemática social que transcende o quotidiano.

E vai ser com o Realismo que a introdução da vida efectiva na composição dos textos literários permite a representação circunstanciada de várias formas da nutrição, de acordo com a diferenciação das classes e modos locais particulares, assim como a situação diversificada das refei- 
ções, de acordo com a altura do dia e o ambiente, em família ou em sociedade. Dando uma imagem bem concreta dos vários tipos de existência e de possibilidades ou opções de vida, o momento de comer dá origem, na nossa ficção oitocentista, a episódios descritivos ricos em pormenor, e de importância decisiva no desenrolar da acção, como se verifica em $A$ Morgadinha dos Canaviais no primeiro encontro entre Henrique e Madalena, no qual esta surge à mesa, orientando a refeição das crianças da casa. A própria poesia, a partir do inovador Cesário Verde, tematiza cenas de repasto, como no conhecido poema "De Tarde", em que, naquele pic-nic de burguesas, se comem talhadas de melão, damascos, e pão-de-ló molhado em malvasia (mas tonalizados, esses alimentos, pelo ramalhete rubro de papoulas que a rapariga descrita traz no decote, os quais agudizam o carácter apelativo dos ingredientes alimentares), passando por vários outros, não sendo possível esquecer a imagística dos chocolates da "Tabacaria" de Fernando Pessoa, nem muitíssima da produção poética posterior. Mas, no séc. XX, um ficcionista português se destaca neste, como noutros campos, e é Aquilino Ribeiro, com frequentes cenas inesquecíveis de refeição que, de modo geral, são marcadas pela sensação, e até exagero, da repleção.

Mencione-se ainda que o grande exemplo literário da relação estabelecida, através da própria escrita, entre os modos da confecção culinária e a composição artística, é o de Proust, com a sua frequente menção da "geleia de vitela" feita pela criada Françoise, que, tal como o recurso a processos da costura (desde o hábil jeito de remendar, da mesma serviçal, à moda nos vestidos de senhora criada pelo costureiro Fortuny), são motivo para reflexões do narrador sobre a arte do romance. Este tipo de alianças, marcadas pela amplificação e diversificação das áreas temáticas, são já característica do Modernismo novecentista.

Deter-me-ei, para exemplificações mais concretas da presença da gastronomia na escrita literária, em dois romances de Camilo Castelo-Branco paradigmáticos nesta questão, Doze Casamentos Felizes e Coração, cabeça e estômago, assim como na obra-prima de Eça de Queirós, A Cidade e as Serras. Do primeiro, datado de 1861, recordo o "Sexto Casamento", com um início ("incipit") que fica na memória do leitor atento ("Uma vez, descia, ou, melhor direi, escorregava eu das Alturas do Barroso, e cismava nas santas proezas de Bartolomeu dos Mártires"), isolo uma cena de surpreendente sugestividade, que descreve o narrador, após ter-se perdido na serra e encontrando abrigo numa casa rústica, sendo comensal a convite dos que a habitam:

Todos saíram da lareira para abancarem a uma longa tábua suspensa em dous cepos, na qual não havia toalha nem garfos. As alfaias únicas eram algumas colheres de pau. Em cada extrema da tábua estava uma broa descomunal.

Seguiu-nos para a mesa uma grandíssima gamela de batatas com a tona, e, ao lado das batatas, uma escudela de sal. Mais de cinquenta dedos, incrustados de lama empedrada, 
convergiram sobre a gamela. Enxerguei esta cousa suja e ignominiosa à luz de dous paus de urze, que ardiam espetados na parede. Fiquei atónito, quando vi aquela gente rolar as batatas na escudela de sal, e comê-las assim!

- Você não come? - disse um dos convivas.

Estendi o braço à gamela, e tirei uma batata que larguei logo, porque me queimava. Riram todos; e alguns, reparando nas minhas mãos, redobraram as gargalhadas, dizendo cousas engraçadas, alusivas à minha magreza. No entanto, estonei a batata, salguei-a, e soube-me que nem manjar de anjos. Em seguida ao apresigo, veio o caldo:era de leite. Caldo de leite, meus amigos, que derrancais o paladar e o estômago com pastéis de ostra, e croquets de carne revelha, e civets de lebre pútrida, e vol-au-vents de marisco! Não sabeis o que é este sadio, o talvez primeiro alimento de Abraão, de Jacob, de Matusalém, e de Sara, minhas senhoras, de Sara, que tomava caldo de leite e tinha filhos na idade em que vossas excelências têm bisnetos!

Cada tigela de caldo era um lago de leite, em que eles formavam, a modo de ilhetas, pirâmides de broa, que comiam e revezavam, e eu também deliciosamente. (CASTELO BRANCO, 1969, p. 125-127)

À primeira vista, nada de mais contrário à elaboração da prática gastronómica que o aqui descrito! Primarismo, impreparação, promiscuidade, uma alimentação frugalíssima: batatas, sal e leite. Mas, vendo melhor, trata-se de alimentos naturais (legumes, uma bebida de origem animal com nutrientes fundamentais) e o condimento básico, o sal, com os competentes cereais, tão a par dos conselhos dietéticos actuais. E o narrador opõe-lhes a confecção requintada de tipo francês, menosprezando-a pela sua demasiada elaboração. Sobretudo, ressalta no texto a unção na comunidade que come com as mãos que se tocam, e com elas tocam directamene os alimentos, em colectivo silêncio respeitoso, só cortado pelo gracejo terno e satisfeito com o hóspede.

A ideologia romântica da valorização do local e do primitivo, que aqui se detecta na atenção prestada à rusticidade e à aproximação com a natureza, persiste quarenta anos depois em A Cidade e as Serras de Eça de Queirós, onde encontramos aquele que é talvez o mais célebre texto da nossa literatura respeitante à alimentação, e, em especial, à valorização de usos e produtos regionais. Jacinto, o português convertido à civilização parisiense, e que já não a pode dispensar, viaja para Portugal a contragosto para uma vilegiatura na sua quinta de Tormes, cujo desconforto receia, e, no termo de acidentada viagem, derreado e esfomeado, depara com o seguinte jantar:

Uma formidável moça, de enormes peitos que lhe tremiam dentro das ramagens do lenço cruzado, ainda suada e esbraseada do calor da lareira, entrou esmagando o soalho, com 
uma terrina a fumegar. E o Melchior, que seguia erguendo a infusa do vinho, esperava que suas Incelências lhe perdoassem porque faltara tempo para o caldinho apurar... Jacinto ocupou a sede ancestral - e, durante momentos (de esgazeada ansiedade para o caseiro excelente), esfregou energicamente, com a ponta da toalha, o garfo negro, a fusca colher de estanho. Depois, desconfiado, provou o caldo, que era de galinha e rescendia. Provou - e levantou para mim, seu camarada de misérias, uns olhos que brilharam, surpreendidos. Tornou a sorver uma colherada mais cheia, mais considerada. E sorriu, com espanto:

-Está bom!

Estava precioso: tinha fígado e tinha moela; o seu perfume enternecia; três vezes, fervorosamente, ataquei aquele caldo.

- Também lá volto! - exclamava Jacinto com uma convicção imensa.- É

que estou que estou com uma fome... Santo Deus! Há anos que não sinto esta fome.

Foi ele que rapou avaramente a sopeira. E já espreitava a porta, esperando a portadora dos pitéus, a rija moça de peitos trementes, que enfim surgiu, mais esbraseada, abalando o sobrado - e pousou sobre a mesa uma travessa a trasbordar de arroz com favas. Que desconsolo! Jacinto, em Paris, sempre abominara favas!... Tentou todavia uma garfada tímida - e de novo aqueles seus olhos, que o pessimismo enevoara, luziram, procurando os meus. Outra larga garfada, concentrada, com uma lentidão de frade que se regala. Depois um brado:

- Deste arroz com fava nem em Paris, Melchior amigo!

O homem óptimo sorria, inteiramente desanuaviado.

- Pois é cá a comidinha dos moços da quinta! E cada pratada, que até suas Incelências se riam... Mas agora, aqui, o Sr. D. Jacinto, também vai engordar e enrijar!

O bom caseiro sinceramente cria que, perdido nesses remotos Parises, o Senhor de Tormes, longe da fartura de Tormes, padecia fome e mingava... E o meu Príncipe, na verdade, parecia saciar uma velhíssima fome e uma longa saudade da abundância, rompendo assim, a cada travessa, em louvores mais copiosos. Diante do louro frango assado no espeto e da salada que ele apetecera na horta, agora temperado com um azeite da serra digno dos lábios de Platão, terminou por bradar:

- É divino!

Mas nada o entusiasmava como o vinho de Tormes, caindo de alto, da bojuda infusa verde - um vinho fresco, esperto, seivoso, e tendo mais alma, entrando mais na alma, que muito poema ou livro santo. Mirando, à vela de sebo, o copo grosso que ele orlava de leve espuma rósea, o meu Príncipe, com um resplendor de optimismo na face, citou Vergílio: 
- Quo te carmina dicam, Rethica? Quem dignamente te cantará, vinho amável destas serras?

$\mathrm{Eu}$, que não gosto que me avantagem em saber clássico, espanejei logo também o meu Vergílio, louvando as doçuras da vida rural:

- Hanc olim veteres vitam coluere Sabini... Assim viveram os velhos Sabinos. Assim Rómulo e Remo... Assim cresceu a valente Etrúria. Assim Roma se tornou a maravilha do mundo!

E imóvel, com a mão agarrada à infusa, o Melchior arregalava para nós os olhos em infinito assombro e religiosa reverência. (QUEIRÓS, s.d., pp 173-175)

O texto defende a confecção de tipo rústico, mas neste caso já com elaboração culinária que, embora simples e despretensiosa, cultiva o sabor e o apuro (o desejo de "apurar" o caldo), que são de tipo gastronómico. E, se há em comum com o exemplo anterior a desconfiança higiénica quanto à transpiração da moça e ao asseio dos talheres, a sensorialidade é também aqui relevada nos termos mais positivos, através da imagem sensual dessa moça (os seus peitos, o passo que abalava o soalho), com o consequente desprestígio do requinte parisiense, compensado literariamente pelo requintado trabalho da composição queirosiana, que exprime maravilhosamente a gradação e a intensidade da satisfação gustativa e olfactiva dos comensais, que se completa com o prazer visual da abundância, da naturalidade, da qualidade dos alimentos e do modo de cozinhar. Veja-se a terrina que fumega, a travessa que trasborda, o louro frango assado, a salada viçosa, o vinho caindo de alto, de espuma rósea, da "bojuda infusa", a qual emparelha com as avantajadas formas da moça, até as atitudes de sorver o caldo e de rapar a terrina, tudo isso emparceirando também com os "louvores copiosos" de quem saboreia. Saboreia e manifesta, a par do sabor, o seu saber erudito da Literatura Clássica, evocando Vergílio "avantajadamente" (veja-se o termo na fala do amigo de Jacinto, o narrador Zé Fernandes) e exaltando a qualidade do vinho. Concluindo-s na reacção do caseiro, que lembra a unção colectiva sublinhada no exemplo anterior, a dar conta de um "infinito assombro e religiosa reverência", pois, não tendo sido prevenido da chegada dos senhores, temia que a refeição improvisada não merecesse a aprovação do patrão, consciente da distância cultural que o afasta, mero analfabeto, de "Suas Incelências".

Se há sabor na Literatura, e da Literatura, ele aí está, nos textos que acabamos de ler!

Mas a prevalência do sabor, na ficção romântica que caminha para o realismo, não está só presente na expressividade estilística da representação, cuidadamente imagética, da comida, mas ainda, em certos casos, na própria estrutura do romance. É o caso de outro magnífico livro de Camilo Castelo Branco, Coração, cabeça e estômago, de 1862. Neste romance, o narrador-personagem passa por três fases sucessivas na sua 
vida, alegóricas de opções determinadas de existência: a do "coração", durante a qual se apaixona em busca da felicidade, sem conseguir atingi-la; a da "cabeça", na qual privilegia os prazeres do intelecto, que o insatisfazem também; e a do "estômago", que se apraz num hino aos prazeres materiais assentes na salubridade simples e nas satisfações imediatas, que não deixam de actuar em profundidade, e dão, na concepção deste texto, o verdadeiro sentido de viver.

Cito o passo em que Tomásia, moça de formas robustas que conquista o narrador com a sua personalidade simples, e na frente dele come bem e bebe melhor, lhe entrega, ao despedir-se, lembranças do seu afecto:

Voltou Tomásia acelerada porque a foram chamar. Logo que pôde falar-me a sós, tirou do peito um embrulho, e deu-mo, pedindo-me que lançasse ao pescoço o que ia dentro do lenço. Despedi-me, e abracei-a. (...)

Depois tornou ela dentro à casa, mandando-me que esperasse um pouquinho, e veio logo com um pequenino alforge.

- É para o caminho - disse ela, atando-o às fivelas da sela.

Dei o último adeus, e Tomásia subiu ao topo de um outeiro donde se avistava grande espaço de estrada, e ali estava acenando-me até que me sumi numa baixa da serra.

Abri um embrulho: era um Agnus-Dei, encastoado em prata.

O lenço, que o envolvia, tinha no centro um coração com muitos aleijões, atravessado por uma flecha que a caprichosa bordadeira deixava ver em todo o seu comprimento, de modo que parecia uma seta grudada ao coração.

Dali três léguas, sentei-me à sombra duns azinheiros, e abri o alforge: era uma galinha assada, uma cabaça de vinho, e um pão.

A leitora de coração fino e melindroso pergunta-me se eu gostei daquilo, se me não seria mais saboroso encontrar um ramo de flores?

Não, minha senhora, eu gostei muito mais de encontrar a galinha, o pão e a cabaça.

Os prazeres das flores cedo-os bizarramente aos amadores de v. exa., e a v. exa . não levo a mal que se ria da filha do sargento-mor de Soutelo, que punha flores aos santos, e cuidava seriamente do estômago das pessoas que lhe eram caras. (CASTELO BRANCO, 1967, p. 246-247)

De novo o afecto (o "gosto" pelo sentimento) se alia ao prazer da comida (que, na sabedoria das nações, é uma forma claramente alargada, e por vezes metafórica, da sensualidade) e à religião, isto é, a uma componente de relação elevada e transcendente que acaba envolvendo corpo e espírito, se não em misticismo, pelo menos em implicação total do huma- 
no. De certo modo, a prática do canibalismo (que não vamos aqui abordar, mas merece referência neste contexto), é uma prática afim, e nisso diferente da antropofagia; e recordo apenas, a esse respeito, que os antropófagos são em geral conotados com concepções da existência marcadas por primitivismo e crueldade, ou, pelo menos, com a redução do ser humano a situações extremas de sobrevivência, e que o canibalismo corresponde a requintes criminosos que em certos casos suportam justificações civilizacionais, surgindo o seu exemplo mais célebre, em Literatura, num romance barroco do século XVII francês, da autoria de Cyrano de Bergerac, a Viagem à Lua (que é também um dos primeiros textos de ficção científica que se conhece), no qual a morte do filósofo, que aí é considerado o expoente da humanidade superior, é presenciada pelos amigos mais queridos, os quais depois se banqueteiam com a carne do seu corpo em sinal de respeito e homenagem, para em si a incorporarem e, desse modo, como que lhe prolongarem a vida.

De modo algo idêntico, o lencinho de Tomásia, um desses lenços bordados que imaginamos como os que ainda hoje se encontram no artesanato do Norte do país, no qual a seta sangra o coração em jeito de amor, envolve o cordeiro místico que ela oferece ao amado como talismã, acompanhado do pão, do vinho e da galinha, como que em junção do alimento físico e espiritual, do amor humano e do amor divino. Assim, a materialidade que o narrador invoca ao dirigir-se, jocosamente, à leitora idealista que decerto preferiria flores em vez da merenda, não é materialidade pura, mas complexo de significação de valor literal que envolve também valores simbólicos multiformes.

O sentido total do livro parece aliás resumir-se num poema que Camilo inclui no final do volume, em jeito simultaneamente sério e auto-paródico, pois que afinal a boa vida que vai ter, casando com Tomásia, comendo bem, engordando e materializando-se, finda... na morte. Mas que outra forma de existência poderá não findar nela??!!

Cabeça e coração senti sem vida.

No estômago busquei uma alma nova.

E encontrá-la pensei... Crença perdida!

Mulher aos pés o coração me sova;

Foge ao mundo a razão espavorida;

E por muito comer desci à cova!

(CASTELO BRANCO, 1967, p. 270-271)

Este sentido paródico da existência, que encontramos em Camilo Castelo-Branco como em nenhum outro dos nossos escritores, vai ser retomado na literatura modernista e pós-modernista do século XX. Encontramo-lo, no que respeita às formas da alimentação, em vários passos da obra de António Lobo Antunes, na qual sublinho um passo significativo, pertencente ao romance Tratado das Paixões da Alma, de 1990. Trata-se da descrição de um jantar em família, que reune semanalmente pais e filhos, um dos quais, o narrador, é membro de uma organização terrorista 
de extrema-esquerda no pós-25 de Abril, e interrompe a refeição de mau grado por ter nessa noite de efectuar um assalto com um colega, no qual aliás este acaba por ser morto. $\mathrm{O}$ cenário da iluminação do jantar adquire, assim, uma função premonitoriamente macabra:

Pedi para chegar mais tarde a Almada por ser dia de jantar no Bairro das Colónias, no apartamento dos meus pais. Converso um bocado na sala com eles, a minha irmã e o meu cunhado, até a minha tia gritar da cozinha que tem a sopa pronta e nos sentarmos todos à mesa a tirar os guardanapos das argolas, debaixo daquele candeeiro de ferro forjado, de lâmpadas a fingirem velas, com teias de aranha entre as correntes mesmo que o limpem de minuto a minuto, e onde houve sempre, nunca entendi porquê, uma ou duas ampolas fundidas, o que faz que a noite da rua se prolongue casa adentro e se distingam mal, na penumbra, os rostos, os móveis e as espinhas do peixe. Não conheço em Lisboa outra zona assim cinzenta e triste [...].

Mas na noite do golpe [...] mal toquei na comida. A minha tia decretou-me mais magro, o meu pai perguntou, a puxar as pastilhas do bolso, se eu sentia palpitações no coração, o meu cunhado sugeriu cápsulas de pólen de gardénia para espicaçar o apetite e reter os intestinos, e a minha mãe quis ir buscar o temómetro a fim de me verificar a febre.

- Lanchei tarde, expliquei eu [...]

- Trinta e seis e seis, triunfou a minha mãe a consultar o termómetro [...]. Pelo menos gripe não é. [...] Espera aí, o que é isso, onde vais tu agora? chamou a minha mãe que entalava de novo o guardanapo no pescoço para recomeçar a canja. Há borrego assado a seguir, deu-te o bicho carpinteiro ou quê, ainda apanhas uma úlcera com as pressas.

- Nós curamos as úlceras infectadas com aplicações de tomate nas costelas, confidenciou o meu cunhado ao meu pai, de cotovelos erguidos em gestos de massagem. Doentes magrinhos, desenganados pelos hospitais, que vomitam sangue de hora a hora.

De facto cheirava a borrego assado para as bandas da cozinha, percebia-se o odor do louro e dos coentros na travessa a lume suave no forno, e era fácil imaginar as batatas coradas, o molho e a salada, mas achava-me já no corredor, a caminho da porta, pensando se iria encontrar um táxi para o Cais das Colunas a tempo de apanhar o barco das nove, de modo que desci as escadas furioso com a falta de tacto do Bancário em marcar emboscadas para uma noite de jantar de borrego, mesmo comido num primeiro direito do Bairro das Colónias, mesmo sob as lâmpadas em lágrima e as teias de aranha, mesmo numa reverberação de mochos em que só as órbitas dos retratos e das pessoas fosforesciam, atormentadas por um luto cruel. (ANTUNES, 2005, p. 213-217) 
A imagem visual e olfactiva do assado corresponde à manifestação da vida que o revolucionário, de nome clandestino "o Estudante", se arrisca nessa noite a perder, a mando do dirigente, "o Bancário”, mesmo que essa imagem esteja ligada a modos conservadores de existir que não atraem a personagem e contra os quais mantém uma luta revolucionária que, no texto, é inglória e grotesca. Sacrifício e prazer opõem-se, pois, mas de modo algo irracional, num texto que aponta também a relação complexa entre vida e morte, dado que a imagem do borrego no forno corresponde à supremacia dos actos sacrificiais, como o que vitimará o colega, denominado "o Artista", não sendo as designações dos membros do grupo arbitrtárias. O início da refeição, menosprezado pela falta de apetite da personagem (que fica de olfacto preso nos eflúvios do borrego, na aparência aqui nada místico, mas que afinal corresponde à fruição descomprometida de viver que agora ele quisera experimentar), prolonga-se na referência a doenças e à utilização dos alimentos de modo não nutricional mas terapêutico, em descoincidência do sentido próprio das coisas na vida quotidiana que é marca da ficção deste autor.

Também como imagem surge, num texto de José Saramago publicado um ano antes, História do cerco de Lisboa, a descrição pormenorizada e detida, saboreada, da confecção do pequeno almoço, um simples café com torradas. Aqui, ao invés, a situação é solitária e comum, vivida na rotina celibatária de um revisor tipográfico, que, não obstante as suas potencialidades criadoras, aceita realizar tal trabalho como meio de subsistência, mas que, ao invés do anterior, extrai da preparação do pequeno almoço, que toma sozinho, uma forma de alegria, no texto representada pela casa inundada do cheiro agradável do café acabado de fazer e das torradas, que barra de manteira com satisfação olfactiva, visual e táctil, e que come com prazer:

Raimundo Silva vai à cozinha, a preparar o café com leite e as torradas com manteiga. As torradas, para este homem com normas e princípios, são quase um vício e verdadeiramente uma manifestação de gula insofreável, em que entram múltiplas sensações, tanto visuais como tácteis, tanto olfactivas como gustativas, principiando pelo brilho da torradeira cromada, depois a faca cortando as fatias, o cheiro do pão tostado, a manteiga a derreter-se, e enfim o prazer complexo da boca, do palato, da língua, dos dentes, a que se cola inefável película escura, queimada e macia, e outra vez o cheiro, agora dentro de si, no céu esteja quem tão sublime coisa soube inventar. Raimundo Silva, um dia, disse estas exactas palavras em voz alta, num rápido momento em que lhe pareceu estar transfundindo-se-lhe ao sangue a obra perfeita do fogo e do pão, que, em verdade, para ele, até a manteiga seria supérflua, dispensável sem maior desgosto, ainda que muito néscio terá de ser aquele que recusasse o que, acrescentado ao essencial, the redobra os apetites e os sabores, é esse o caso do pão torrado e da manteiga, de que vimos falando, 
seria também o caso do amor, por exemplo, se dele tivesse o revisor mais ampla experiência. (SARAMAGO, 1989, p. 55, grifos meus)

Primária e simples refeição no uso contemporâneo, as torradas representam-se aqui também no prazer da circunstância: o brilho do cromado, o corte da faca, a visão sensual do tostado e do derretido, a sensorialidade completa, inclusive a dos vários tipos de toque dos órgãos gustativos convocados, tudo converge em Saramago para a dar como imagem primordial da alimentação, "a obra perfeita do fogo e do pão", que o autor explicitamente assemelha ao amor. ${ }^{5}$

Ao longo de todo o século XX a nossa literatura é pródiga em representações interessantes da alimentação, com referências a modos culinários vários, e assume frequentemente a actividade reflexiva, selectiva, localizada ou cronologicamente situada das preocupações gastronómicas. Citarei ainda um romance que, a meio do século, se empenhou em representar formas diversas dos hábitos alimentares regionais, no caso referente aos Açores. Trata-se da obra-prima de Vitorino Nemésio, Mau Tempo no Canal. Neste livro, refeições, modos de confecção, apresentação dos pratos, formas sociais da alimentação conjunta são constantes, se bem que subordinadas à acção e por isso muitas vezes apresentadas fragmentariamente; o que acrescenta à sua importância ficcional, uma vez que esses modos intervêm na caracterização das personagens e no seguimento da intriga. Assim, a personagem central, Margarida, extraordinária figura de mulher, surge no capítulo sugestivamente intitulado "Uma Toalha Bordada" (XXVI) como uma temporária "dona de casa":

Um dos secretos encantos de Margarida era precisamente tomar sobre si o peso de uma casa. Atava um avental barrado por cima da saia, vestia uma blusa usada, e, de manguinha curta, picava as couves, batia gemas de ovos para ensaiar pratos simples, mexia as rodelas de cebola-albarrã na panela. Outras vezes, farta de lume e de comidas, mandava chamar a mulher do Espadinha e fechava-se todo o dia no quarto a ler e a bordar, ou, se o nevoeiro abria um pouco, desarvorava pelos atalhos da serra ou da borda do mar. (NEMÉSIO, 2002, p. 236)

Note-se que "o peso de uma casa" é, aqui, a culinária, sendo que Margarida é uma menina que tem criados para lhe fazerem tudo e que, neste caso, se encontra isolada a cuidar de um doente, justamente o seu dedicado servo Manuel Bana, atacado pela epidemia de peste que se desencadeou no Faial, estando os dois de quarentena; e cozinhar reduz-se, neste caso, a gestos metonímicos como picar, bater e refogar. E é nesse capítulo que, finda a quarentena, recebe amigos a quem oferece de lanchar: tomam chá e scones (com carnes frias para seu esfomeado irmão Pedro) sobre a toalha bordada por Margarida enquanto cuidou do doente. André, o amigo, faz-lhe a corte (ela, apaixonada por outro) e acabarão por casar, e não é irrelevante o teor desta conversa de ambos, pois ele, que vive em São 
Jorge, conta justamente "a história do casamento do sr. Constantino Barreto, morgado da Urzelina e seu avô, com a sra D. Petronilha Teixeira Borges Acompanhado, morgada do Norte Grande". O dito avô, formado em Teologia e quase padre, fica sem o irmão, o Morgado, tendo por isso de garantir a sucessão da casa, para o que faz a corte, após criteriosa escolha racional, a uma senhora que nem conhece, essa D. Petronilha, "uma viúva ainda fresca mas parece que feiinha": "mandou-lhe de presente um alqueire de pão de cabeça (estava-se no Espírito Santo) e, logo adiante, em Dezembro, um cesto de camélias e um casal de leitões arraçados”. Em resposta, ela mandou "muitos recados ao sr. Morgado Constantino, e aquela giga na burra: dois queijos assim..., rodados, como já hoje se não fazem!” (NEMÉSIO, 2002, p. 241). O namoro serôdio, com troca de presentes alimentares, lembra outro dos Casamentos Felizes de Camilo Castelo-Branco, o “Terceiro", que se entretece do mesmo tipo de relações.

Ora este encontro dos futuros noivos de Mau Tempo no Canal, que ainda mal se conhecem e nem são namorados, dá-se, pois, sob o signo da gastronomia (os scones e as carnes frias opõem a cerimónia com os convidados à desenvoltura com o membro chegado da família), e é na sequência da perseguição a uma baleia que, mais tarde, Margarida irá dar à costa em São Jorge com um grupo de pescadores, sendo acolhida em casa dos barões da Urzelina, pais de André. Aí fica alojada num quarto que, diz-lhe a baronesa, está "reservado para o casamento do meu André" (o que é premonitário do noivado que vem a acontecer) e Margarida passa uma temporada à espera de transporte para o Faial, que não há, animando aquele casal que vive isolado perto das Velas, e ainda não refeitos "daquela pedra de escândalo lançada aos fundões do seu sossego" que foi a chegada aventurosa da menina. "Nos seus rostos fechados por mais de sessenta anos de pasmo e de sopas de leite, à vista dos perfis vulcânicos das ilhas do Pico e do Faial, luziam olhares desconfiados" (NEMÉSIO, 2002, p. 274), diz-nos o texto, e a alimentação doméstica é praticamente a distracção maior daquele agregado familiar onde só estão o casal, a visitante forçada e os criados, esclarecendo-se no capítulo "Pastoral” (XXII):

As horas iam pelo dia e pela noite fora [em] conversas vagarosas e nos chás a todo o instante. Leite ao acordar - quando não era chá com roscas. Chá às dez horas ou onze horas, depois de uma refeição ligeira... Chá depois do caldo e do cozido ou do assado, às duas da tarde... Chazinho à merenda, com massa sovada torrada e guardada em latas gargaludas... Chá à ceia, ao deitar... Chá... chá... chá... A baronesa, quase transparente na sua pele rugosa, e muito cingida às saias, enchia duas vezes a chávena. O barão preferia geralmente leite. (“Não sou muito chazeiro...") Às onze horas esmiolava metade de um pão de milho numa malguinha branca e enchia-a de um leite espesso, perfumado, que caía de alto nas sopas com a espuma a ferver. (NEMÉSIO, 2002, p. 287) 
Encarado por vezes como um romance regional, como o são a maioria dos de cariz não urbano, ou pelo menos arredados das capitais, este texto valoriza produtos da "terra" e da natureza, hábitos primitivos e saudáveis, a gordura sadia que negligencia a afectação elegante, ao mesmo tempo que entende este tipo de comportamento como condicionador do marasmo da existência, conservadora e sem potencial de sonho, que é o contrário da de Margarida, a qual se sente, porém, algo seduzida por tais hábitos ancestrais, talvez por isso escolhendo um futuro de compromisso.

\section{MUNDO GASTRONÓMICO E RECURSOS CULTURAIS: A ARTE DE COMPOR UMA EMENTA}

A Gastronomia de hoje, em todo o caso parte dela, constrói, a partir da ancestralidade, paladares inovadores sobre modos de confecção e aliança de alimentos que se baseiam no insólito e no surpreendente. Dito de outro modo, a gastronomia invade quase todos os níveis da culinária, ao menos em propósito publicitado, com realce para a cozinha regional e a cozinha "gourmet", que se ligam com frequência.

Sendo, sem dúvida, um recurso cultural, a gastronomia pode interagir com dados patrimoniais topográficos, procedendo à valorização dos lugares e não sendo insensível à História, seja esta entendida como memória de gerações passadas, seja como necessidade de progresso e de rotas para o futuro. A testemunhá-lo estão, sobretudo, a concomitância de hábitos que se preservam (o azeitinho português, o néctar das nossas vides, um ror de usos que nos são próprios em matérias e modo de as usar) com as inovações contemporâneas, tal como as de exóticas proveniências, nesta nossa época em que o hibridismo é quase uma manifestação global.

Mas a gastronomia vive também muito da explicitação verbal das iguarias, e as palavras podem fazer crescer água na boca, evocando os pitéus!

Enunciar a comida, em "menus" e "cardápios", implica serventias e critérios diferenciados, desdo o puro inventário de um elenco, oferecido à hipótese da escolha, à indicação de preços e as intenções apelativas. Por isso mencionava eu de início que não é indiferente falar de "bacalhau com todos" e de "tripas à moda do Porto", com potencialidades não só descritivas mas sugestivas, como o são também a "caldeirada à fragateiro" ou o "pudim do abade de Priscos", e tantas outras designações. O seu estudo daria um longo trabalho de investigação e análise, em Estudos Culturais de índole comparatista, de alcance não apenas discursivo mas antropológico e social.

Os modos de enunciar as designaçãos dos "pratos" encontram, na tradição, raízes de proveniência regional, profissional, autoral, etc., tanto como de inspiração criativa. Modernamente, a elaboração das ementas apresenta casos de sugestividade que chegam a evocar a imagística do trabalho poético, dele parecendo "pastiches". A chamada cozinha de "gourmet" torna parte do consumo, em muitos restaurantes, "a explicação do chefe", ou de 
um seu substituto encartado, que faz a explanação dos materiais utilizados e da confecção da iguaria que acaba de servir-se, de modo a que o consumidor dela frua, justamente aliando o sabor ao saber. Ora o que é isto senão uma espécie de "explication de texte", como diriam os mestres académicos franceses (também considerados mestres na cozinha, afinal), explicação que é suposta aumentar a fruição do prato (do texto) apresentado.

Até o modo de apresentação à mesa pode ser especialmente cuidado, seja no registo "gourmet" seja no registo popular, desde o serviço de baixela até à sardinha assada que se come sobre a fatia de pão caseiro, e a sua importância pode constatar-se no texto queirosiano de Tormes, atrás reproduzido (a "pratada" dos trabalhadores e o receio higiénico de Jacinto a limpar o garfo escuro à toalha, em profundo contraste com o requintadíssimo serviço de mesa que fora descrito na sua mansão parisiense). $\mathrm{O}$ mesmo se pode dizer quanto a ordem na sequência dos pratos, quer nos "menus" quer nas refeições, que hoje em dia se simplificou no que respeita à quantidade de pratos apresentados. Também o arranjo expositivo na apresentação é cuidado, e há mesmo casos actualmente (desconte-se-me algum exagero...) que chegam a assemelhar-se à chamada "instalação" em artes plásticas!

Nesse aspecto da apresentação, há banquetes tradicionais, ou certos pratos, que ficam como imagens de marca incomparáveis, tais os "flambés" da "Tour d’Argent" em Paris e, em requinte máximo, o Banquete Nobel, que se realiza na primeira quinzena de Dezembro em Estocolmo, e aqui recordo. Nele merecem especial menção a disposição das longas mesas em estrela, o serviço dos empregados dimensionado em harmónica movimentação ballética (num rigoroso simultâneo de todos os gestos para todas as mesas), e sobretudo o "flambé" final da sobremesa, suportado por uma meia centena de empregados que descem a escadaria em fileiras na sala subitamente às escuras, como que empunhando archotes - sendo estes a única coisa que na altura se vislumbra no denso espaço escurecido, sugerindo chamas que vêm esvoaçando (simbologia do espírito criador?) para chegarem até nós, comensais atónitos (para a maior parte, é uma surpresa!), que só no instante em que os servem verão enfim que se trata de um doce iluminado (e gelado, em antífrase estilística) o que lhes é dado a comer. Sublime! Ou: a versão moderna da Gata Borralheira, enquanto sonho realizado para qualquer beneficiário do prémio e seus admiradores.

Não valerá a pena insistir na diferença entre requinte e pretensiosismo, que aliás existe em todas as artes, mas que no caso da actual cozinha de "gourmet" pode tornar-se ostensiva; basta ver, numa revista corrente, a Time de 12 de Julho de 2010, um artigo intitulado "Celebrity Chefs: It's not just about the food", e compreender-se-á de que modo a ilustração mediática favorece a despesa encarada como luxo, e a invenção "gourmet" não passa muitas vezes de malabarismo alimentar. 
Insisto, porém, no modo como a nutrição se serve da palavra. E darei exemplos das ementas do "Restaurante Valle-Flor", no Hotel Pestana Palace de Lisboa, elaboradas por determinados chefes, os quais me apraz homenagear. (Não estou a fazer publicidade, juro, estou simplesmente a estudar modos de formulação verbal). Estas ementas são um caso feliz de aproximação entre o descritivo e o sugestivo, com recurso a modos literários de dizer, que não raro se aproximam do amaneirado e do "kitsch", de índole neo-barroca, mantendo no entanto uma auto-ironia que reconduz o "kitsch" ao bom tom. A estilização leva-se ao extremo, justificada pela consonância harmónica que mantém com o ambiente da sala, e até do palácio, de um rococó tardio e extemporâneo que a propensão pós-moderna actual ainda leva a apreciar - e estou a considerar ementas de há quatro ou cinco anos.

Cito algumas das designações de pratos, extraídas de ementas relativas a 2006 e 2007, a maioria das quais com a assinatura do Chefe Costas. E a declaração de princípios do chefe anterior, Aimé Barroyer, dada num intróito, é reveladora: "É com pedacinhos desta terra, que abracei com entusiasmo, que construo a minha interpretação da cozinha portuguesa. Que todas as cores e cheiros desta paisagem se juntem assim neste salão e, sobretudo, que esta seja uma festa para os vossos sentidos." (sublinhados no original). Localização (terra e sala), interpretação (no duplo sentido de "execução" e de "leitura" pessoal), sensorialidade (diversificada) e celebração (apontada como objectivo) são pois componentes da construção culinária anunciada. Vejamos a sua concretização na designação de alguns pratos:

Das nossas lezírias, as enguias assadas em crosta e fritas de escabeche, alho novo e tomates marinados juntos numa alhada

Um grande achado... abrótea arrepiada e assada em crosta de pastel de bacalhau, cenoura no forno e sopinha de agriões mouros

Um abafo de magusto... cherne da Nazaré em abafo de água-pé num caldo de esteva, tronchas, meadas de castanha e óleo de eucalipto

Da antiga Lisboa esta lembrança... perdiz de peitos feitos com as britadas e sardinhas anchovadas assadas, maçã bravo de Esmolfe no forno com milhos e tomilho

Da ria Formosa ...escondidos na areia Linguado a selar lingueirões em abafo de perpétuas das areias, concassé de lula, tomate e azeite negro

Toiro das lides numa festa brava com Alternativa Farpas, farturas, prego, ovo a cavalo e flores... as pedrinhas de sal a rematar

As rainhas num verdadeiro arraial Sardinhas de Sines albardadas em pastel de bacalhau com eles uma mista a trincar e o caldo verde a molhar 
As designações que apresento foram seleccionadas um pouco a esmo, mas sublinho que, nas ementas, elas se encontram estruturadas em grupos, os quais relevam também de preocupações quanto à estrutura, não só do repasto como do texto. No que respeita à estilística, que é o que mais nos diz sobre a elaboração verbal que induz o cliente na escolha do prato, observa-se em geral uma vigorosa liberdade de expressão, a qual no entanto se alia à demarcação das espécies e dos géneros, mas deles se desprende para criar alianças imaginativas e oníricas (com recurso a significados tradicionais: "fritas de escabeche" ou "abrótea arrepiada", já que o escabeche não costuma incluir fritura, e o arrepiar da pescada, com a mão cheia de sal, para a enrijar, era coisa das nossas avós!) e, direi sem receio, de cariz poético ("ovo a cavalo e flores", por exemplo), que chega a incluir o versejar ("uma mista a trincar e o caldo verde a molhar"), assim como ironia e gracejo conotativos: "juntos numa alhada" ou a "perdiz de peitos feitos"), implicando objectivos de requintadada e divertida transfiguração. Nem repugna pensar que a composição verbal dos textos tenha sido encomendada a algum artesão da escrita!

Atentemos, a seguir, em outras designações de índole poética, a primeira das quais algo surrealizante, e as outras trabalhando na linguagem a enumeração, os diminutivos, a metáfora ("raízes esquecidas"), as transposições (veja-se o terceiro exemplo) e, muito bem concebida, a aliança entre o lugar de proveniência da espécie, ou do hábito culinário, com a expressão contemplativa (na "maré", no "passeio algarvio", na "levada") e o humor ("a pera bêbeda”), entre vários outros traços curiosos.

\section{Num arraial, um piano com duas notas do mar}

as sardinhas como os ossos no piano de porco assadas, migas soltas de favinhas, alfádega, broa de milho e piso de pimento

Hoje o clássico bife do beijinho...Estufado lentamente em borras de vintage e engaço, gratin com abrunhos secos e chips de raízes esquecidas

O camarão e a lula na praia como um raio de sol Um assado em sauté, outra cheia com migas de poejos e grelhada, lascas de aboborinha, azeiteiras e beldroegas

Um sarrabulho? E grande! Fritada de coelho de olho preto em marinada de sorça, seu arroz como uma cabidela em ouriço de castanhas

\section{Piscar de olhos a despertar a maresia...}

Cavalinha do Cabo Espichel assada, uma de camarão uma de amora e outra de amêijoa boa e seu xarém de hortelã da ribeira

\section{Um embalo ao sabor da maré}

Sapateira e camarões num recheio a lembrar um croquete num lombo de corvina do estuário e caldo à fragateira 


\section{Num passeio algarvio uma brisa senti...}

Salmonete de Quarteira no forno com flor de sal sumagre, figo fresco e presunto em sopa de tomate chuchu

\section{$O$ regresso de uma levada inspirou-me}

Espada no forno com pinhões e azeitonas galegas, banana, maçã, espuma de queijo da Serra e pó de toucinho de fumo

\section{A bêbeda do costume ...}

Pêra Rocha entorpecida e assada no abafo de vinagre de mel, caroço de queijo cabra Granja numa trouxa

Verifica-se, pois, em quase todas as designações, uma expressão figurada de intensa carga retórica: metáforas e sinédoques, associações de ideias promovendo comparações, metalepses, animização afectiva dos alimentos, inversão (de efeitos literários) da ordem lógica das palavras na frase, cuidado na enunciação rítmica; e cultivam-se predominantemente as designações locais, porém apresentando-as em rodeios sintácticos que aliam o insólito ao humor e à ironia, emulando mesmo com a enunciação em verso. E acrescento mais alguns casos:

Raia e camarão... pregados ... Abraçados e assados, pingados com limão, óleo de eucalipto e a lembrar uma marinheira, os mexilhões

O choco com ovas fingidas... Assado com pérolas tintas, ostras na chapa a fechar, colherada de batata-doce, espuma de azeite e laranja

Insólito... talvez!!! Foie gras de pato corado com flor de sal e pimenta do paraíso, dobrada favo de mel lacada numa sopinha de fava rica

Homenagem ao fiel amigo... Com ele os companheiros de sempre / azeite, azeitonas, alho, salsa e cebola

Leitão assado vincado pela tradição Laranja, alho, pimenta e pão / da nossa interpretação...

De um legado transmontano... Cachaço de bísaro guisado e assado com crosta de alheira, / pencas e casulas numa sopa azeda

É fundamental que as ementas apresentadas possam enquadrar-se no tipo de sala onde a refeição se serve. Ora, o ambiente de pastoral palaciana dos salões do Restaurante Valle-Flôr coadunam-se com o verbalismo guindado dos menus, provocando um sorriso no cliente, que é de espanto algo deslocado pela novidade, mas também de satisfação - como que a prever o gosto a saborear, tal como no texto citado de Saramago se diz: muito néscio terá de ser aquele que recusasse o que, acrescentado ao essencial, the redobra os apetites e os sabores. 
A comida, acto primacialmente instintivo, torna-se então actividade estética, pelo menos nesta espécie de "partitura" musical que aqui a condiciona, ou de poema, com o qual, na ideia, vamos saborear os alimentos - ou estaremos, sobretudo, saboreando as palavras que no-los fizeram escolher, e dão o tom, como no início de uma partitura, ao nosso seleccionadíssimo e transfiguradíssimo repasto?? Mas nem só de poesia se nutre a formulação dietética, e alguns dos exemplos acima vincam por vezes demasiado a componente "surpreendente" (termo de que a época hodierna faz uso frequente, a significar a sua exaustão quanto a excitantes), o que, bem se percebe e melhor se entende, é feito de modo a ir ao encontro de certo tipo de cliente endinheirado e apreciador do insólito dispendioso e preciosista.

Mas não esqueçamos que o inverso também foi feito na História da Cultura, e no sentido mais erudito do termo, enriquecedor para o futuro linguístico ocidental - daí insistirmos em sublinhar que trabalhos sobre estas matérias, situados na área científica dos Estudos Culturais e versando aspectos que caracterizam a cultura de massas, não são despiciendos no meio académico nem na actividade ensaística em geral. $\mathrm{E}$ tal foi feito há cerca de quinhentos anos pelo Humanismo, o qual em princípio contrariava osmoses deste tipo - mas talvez só em princípio... Recordamos brevemente, a finalizar, o grande poeta francês Du Bellay, do século XVI, contemporâneo do já citado Rabelais.

Du Bellay teve como principal objectivo doutrinário da sua actividade de poeta e pensador, até na sua qualidade de poeta oficial da corte, o de "defender" e "ilustrar" a Língua Francesa. Este objectivo devia-se à sistemática redacção, na época, dos textos importantes em latim, menosprezando-se a língua do tempo por não ser ela suficientemente rica para comunicar a diversidade da realidade coeva, nas ideias, nos objectos, nos sentimentos. Foi essa uma preocupação da maioria dos escritores de então, mas Du Bellay escreveu mesmo um livro, a Defesa e Ilustração da Língua Francesa, de 1549, no qual apresenta processos concretos para o enriquecimento do francês. Designava ele esses processos como subordinados ao que chamou o "princípio da nutrição", isto é, considerando que a capacidade extensiva e a maleabilidade de expressão da língua se baseariam no alargamento vocabular e na transposição de fórmulas adoptadas de outras línguas, propôs (e praticou-o na sua vasta obra, sendo seguido pelos escritores da época) que esses dois tipos de formas lexicais novas se incorporassem no francês, fornecendo-lhe assim um "alimento" fundamental para a criatividade. E assim a metáfora alimentar contribuiu para encorpar a tradição literária que conhecemos, sendo utilizada com proveito nas línguas românicas, as quais, na sequência destes procedimentos, irão fixar-se como línguas nacionais e patrimoniais a partir do século seguinte.

Não só na língua e na literatura a metáfora da alimentação é procedente, conforme tivémos ocasião de sublinhar ao longo deste razoado. Mas também sem metáfora ela é preciosa, e, ainda mais, sem conotação alguma. Foi o caso deste colóquio, onde apreciámos particularmente a rela- 
ção entre a reflexão gastronómica produzida e a que nos foi experimentalmente dada a conhecer, em particular nas especificidades (especialidades!) regionais, as quais aumentaram em muito o nosso saber do sabor.

\section{REFERÊNCIAS BIBLIOGRÁFICAS}

ANTUNES, António Lobo. Tratado das Paixões da Alma. ed. "ne varietur". Lisboa: Dom Quixote, 2005

NEMÉSIO, Vitorino. Mau Tempo no Canal. 6. reimp. Lisboa: IN-CM, 2002.

CASTELO BRANCO, Camilo. Coração, cabeça e estômago, 5. ed., conforme a 2 ed., última revista pelo autor, com fixação do texto por Carlos Brejo da Costa. Lisboa: Parceria A. M. Pereira, 1967.

Doze Casamentos Felizes. 8. ed., conforme a 2. ed., última revista pelo autor. Lisboa: Parceria A. M. Pereira, 1969.

QUEIRÓS, Eça de. A Cidade e as Serras. Porto: Lello \& Irmãos, s.d..

SARAMAGO, José. História do Cerco de Lisboa. Lisboa: Caminho, 1989.

Recebido para publicação em 29/10/2013

Aprovado em 27/02/2014

\section{NOTAS}

1 Texto originalmente publicado na Revista Tellus, n. 53, Revista de cultura transmontana e duriense, dirigida por António Manuel Pires Cabral, Vila Real, Outubro 2010, p. 36-55..

2 Resumo e tradução produzidos pela Revista Abril para esta publicação.

3 Veja-se, no excelente opúsculo que o Grémio Literário Vila-Realense publicou por alturas deste colóquio, de Francisco Sampaio, com excertos e comentários respeitantes ao Livro de Cozinha da Escritora Emília de Sousa Costa, a designação de algumas receitas, que vão neste sentido, tais como o "Bacalhau namoradinho" ou a "Perdiz à cónegos".

$4 \mathrm{Na}$ obra atrás mencionada, é dado um breve e útil historial da cozinha ao longo dos tempos.

5 Nota pessoal: escrevo estas palavras a 18 de Agosto, o autor deixou-nos há dois meses. Recordo a última vez em que almoçámos juntos, ele comia e eu explicava-lhe o intento de aqui escrever sobre esse trecho, que lhe evoquei. José parou de mastigar, olhou-me fixamente sem palavras, os olhos como que se alheando em retorno interior a essas linhas, e brilharam-lhe então intensamente, com um sorriso cintilante, dos mais lindos que lhe vi, pleno do gosto de se sentir compreendido. Este texto era-lhe querido, nesse livro que escreveu após ter conhecido Pilar. 